\title{
Resection and Reconstruction is the Procedure of Choice for Giant Cell Lesions of Small Bones: A Case Report and Literature Review
}

\author{
Jiannan Li \\ China-Japan Union Hospital of Jilin University \\ Weizhong Zhang \\ China-Japan Union Hospital of Jilin University \\ Guangzhi Wu \\ China-Japan Union Hospital of Jilin University \\ zhan zhang ( $\square$ zhangzhan@jlu.edu.cn ) \\ China-Japan Union Hospital of Jilin University
}

\author{
Case report \\ Keywords: Giant lesion of small bones, Giant cell reparative granuloma, Surgery, Curettage, Resection, Reconstruction \\ Posted Date: June 28th, 2021 \\ DOI: https://doi.org/10.21203/rs.3.rs-633635/v1 \\ License: (c) (i) This work is licensed under a Creative Commons Attribution 4.0 International License. Read Full License
}




\section{Abstract}

Background: Giant cell lesion of small bones (GCLSB), also known as giant cell reparative granuloma, is a rare tumor-like condition occurring in the small bones of the hands and feet. GCLSB lacks specific clinical, radiological, and histological manifestations. There are no standardized protocols for treatment.

Case presentation: Here, we report a 16-year-old male with recurrent GCLSB in the proximal phalanx of the left thumb. The lesion was successfully resected with bone grafting.

Conclusions: We summarized the characteristics of 33 reported cases of GCLSB from 1983 to date, including gender, age, lesion sites, recurrence, and treatment. We conclude that resection and reconstruction with curettage is the treatment of choice.

\section{Background}

Giant cell lesion of small bones (GCLSB) is an infrequent tumor-like condition occurring in the hands and feet. Also known as giant cell reparative granuloma (GCRG), GCLSB is defined by the World Health Organization as a lesion consisting of fibrous tissue with hemorrhage, hemosiderin deposits, irregularly distributed giant cells, and reactive bone formation ${ }^{1}$. Because the features of GCLSB lack specificity, diagnosis requires a combination of clinical examination, imaging, and pathology. At present, there is no standardized treatment for GCLSB, primarily because there are so few reports. We present a case of recurrent GCLSB of the phalanx treated with surgical resection. We discussed the clinicopathological features of the disease and its treatment and provided a review of the literature.

\section{Case Presentation}

In August 2017, a 16-year-old male presented with swelling and pain of the left thumb. A lump the size of a fingernail with pain on palpation was found on the radial side of the left thumb. There was no previous history of trauma. He went to Central Hospital of Siping city in September 2017 . Xray revealed a lytic expansile lesion of the proximal phalanx of the left thumb (Fig. 1). The patient was treated with curettage, $99.5 \%$ ethanol sterilization, and grafting in September 2017. Postoperative pathology identified giant cell reparative granuloma.

In July 2018, the patient presented with recurring swelling and pain of the left thumb. As the lump grew progressively, the patient came to our hospital in September 2018. Laboratory examinations (complete blood count, prothrombin time, partial thromboplastin time, and serum level of calcium) were within normal ranges. Magnetic resonance imaging (MRI) revealed a distended lesion in the proximal phalanx of the left thumb that presented with high signal intensity in in both enhanced T1-weighted and enhanced T2-weighted images (Fig. 2). The border was distinct and the cortex was intact. The surfaces of the joints were smooth. Subsequently, the proximal phalanx, interphalangeal joint, and metacarpophalangeal joint of left thumb were resected. Iliac bone measuring $3.0 \times 1.0 \times 1.0 \mathrm{~cm}$ was grafted. The interphalangeal joint was held in place longitudinally and cross-fixed using two Kirschner wires. The stop point of the adductor pollicis was reconstructed at the base of the proximal phalanx. The hallux abductor brevis stop was sutured to the radial side of the metacarpophalangeal capsule (Fig. 2). Histological analysis revealed heterogeneous fusiform or fibroblast-like cells with occasional mitotic figures. Some fusiform cells were filled with lipid without definite atypia. There were scattered multinucleated giant cells (Fig. 2). No clinical or radiographic evidence for a recurrent lesion was found at 17-month follow-up (Fig. 3). The palm-to-palm test of the thumb was negative (Fig. 3). Pinch strength was measured using the Biometrics E-LINK system (Biometrics Limited, US). The pinch strength of the left thumb was slightly lower than normal (Table 1). Using the AMA impairment guidelines, the analysis suggest that the left upper limb lost $12 \%$ of its function after surgery.

\section{Literature review}

We performed a Medline literature search to identify cases of GCLSB. English and non-English-language papers were searched in PubMed using a combination of terms: (((((((metacarpal) OR (carpal bones)) OR (phalanx)) OR (metatarsal bones)) OR (tarsal bones)) OR (hand)) OR (foot)) AND (giant cell reparative granuloma)) OR (giant cell lesion of small bones). The search was carried out using the literature from 1983 to the present. The data available are summarized in Table 2. We were able to find 33 patients (include this study) with 37 lesions. The 33 patients included 16 men and 17 women with a mean disease duration of 22.3 years (range 4.5 to 67 years). Most patients were in their second decade (48.5\%) followed by the third (21.2\%), first ( $8 \%)$, fourth (9.1\%) and fifth decades (9.1\%). The lesion occurred most often in a phalanx (17 lesions, $45.9 \%)$, followed by metacarpal (11 lesions, 33.3\%), metatarsal (five lesions, 15.1\%), carpel bones (three lesions, 9.1\%), and calcaneus (one lesion, 3\%). Pain (19 cases), swelling (12 cases), and pathological fracture (four cases) were the symptoms mentioned most often. Among the 38 lesion sites, 26 were treated with curettage, ten were treated with resection and two were treated with amputation. Recurrence (in nine lesions) occurred only after curettage that proceeded a second surgery. Five of the nine lesions were treated with resection, three were treated with curettage and one was treated with amputation (Table 2). Regardless of the operation frequency, 19 lesions (51.3\%) were finally cured with curettage, 16 were cured with resection (40.5\%), and three were cured with amputation (8.1\%). 
Table 1

Pinch strength analysis

\begin{tabular}{|c|c|c|c|c|c|c|c|c|c|c|}
\hline \multicolumn{5}{|l|}{ Left } & \multirow{2}{*}{$\begin{array}{l}\text { Unit: kgs } \\
\text { Position }\end{array}$} & \multicolumn{5}{|l|}{ Right } \\
\hline try1 & try2 & try3 & Avge & CV\% & & try1 & try2 & try3 & Avge & CV\% \\
\hline 5.0 & 5.1 & 4.8 & 5.0 & 3.1 & Key & 8.3 & 7.6 & 8.0 & 8.0 & 4.4 \\
\hline 4.2 & 3.7 & 3.9 & 3.9 & 6.4 & Three jaw & 7.7 & 7.5 & 7.6 & 7.6 & 1.3 \\
\hline \multirow[t]{3}{*}{2.8} & 2.6 & 2.8 & 2.7 & 4.2 & Tip to tip & 5.6 & 5.1 & 4.9 & 5.2 & 6.9 \\
\hline & index & mid & ring & small & \multirow[t]{2}{*}{ Thumb to } & index & mid & ring & small & \\
\hline & 2.4 & 1.4 & 1.1 & 0.4 & & 4.4 & 2.6 & 2.3 & 1.3 & \\
\hline
\end{tabular}


Table 2

Giant cell lesions of small bones. Systematic review of the literature from 1983 to 2020. NR = Not Reported

\begin{tabular}{|c|c|c|c|c|c|c|c|c|c|}
\hline Year & Authors & $\begin{array}{l}\text { Number } \\
\text { of } \\
\text { patients }\end{array}$ & $\begin{array}{l}\text { Age } \\
\text { (years)/Gender }\end{array}$ & Site & Symptom & Treatment & Recurrence & $\begin{array}{l}\text { Treatment } \\
\text { after } \\
\text { recurrence }\end{array}$ & $\begin{array}{l}\text { Follow- } \\
\text { up } \\
\text { (months) }\end{array}$ \\
\hline \multirow[t]{3}{*}{1983} & $\begin{array}{l}\text { Glass et } \\
\text { al. }^{2}\end{array}$ & 3 & 27/Male & $\begin{array}{l}\text { Metacarpal, } \\
\text { capitate[ } \\
\text { lunate }\end{array}$ & NR & Curettage & No & - & - \\
\hline & & & 26/Female & Phalanx & Painless & $\begin{array}{l}\text { Curettage and } \\
\text { grafting }\end{array}$ & Yes & $\begin{array}{l}\text { Resection and } \\
\text { reconstruction }\end{array}$ & 48 \\
\hline & & & 13/Male & Phalanx & Swelling & $\begin{array}{l}\text { Curettage and } \\
\text { grafting }\end{array}$ & Yes & Amputation & 121 \\
\hline 1985 & $\begin{array}{l}\text { Caskey et } \\
\text { al. }^{3}\end{array}$ & 1 & 24/Male & $\begin{array}{l}\text { Metacarpal, } \\
\text { capitate }\end{array}$ & $\begin{array}{l}\text { Swelling, } \\
\text { pathologic } \\
\text { fracture }\end{array}$ & $\begin{array}{l}\text { Curettage and } \\
\text { grafting }\end{array}$ & No & - & 13 \\
\hline \multirow[t]{3}{*}{1985} & $\begin{array}{l}\text { Merkow et } \\
\text { al. }^{4}\end{array}$ & 3 & 46/Female & Phalanx & $\begin{array}{l}\text { Pain, } \\
\text { swelling }\end{array}$ & $\begin{array}{l}\text { Curettage and } \\
\text { grafting }\end{array}$ & No & - & 14 \\
\hline & & & 16/Female & Metacarpal & $\begin{array}{l}\text { Pain, } \\
\text { swelling }\end{array}$ & $\begin{array}{l}\text { Curettage and } \\
\text { grafting }\end{array}$ & Yes & $\begin{array}{l}\text { Curettage and } \\
\text { grafting }\end{array}$ & 24 \\
\hline & & & 14/Male & Phalanx & $\begin{array}{l}\text { Pathologic } \\
\text { fracture }\end{array}$ & $\begin{array}{l}\text { Curettage and } \\
\text { grafting }\end{array}$ & No & - & 24 \\
\hline 1987 & $\begin{array}{l}\text { Wenner et } \\
\text { al. }^{5}\end{array}$ & 1 & 13/Male & Phalanx & Swelling & $\begin{array}{l}\text { Curettage and } \\
\text { grafting }\end{array}$ & Yes & $\begin{array}{l}\text { Resection and } \\
\text { reconstruction }\end{array}$ & 12 \\
\hline 1989 & $\begin{array}{l}\text { Robinson } \\
\text { et al. }{ }^{6}\end{array}$ & 1 & 17/Male & Calcaneus & $\begin{array}{l}\text { Pain, } \\
\text { pathological } \\
\text { fracture }\end{array}$ & $\begin{array}{l}\text { Curettage and } \\
\text { grafting }\end{array}$ & No & - & 24 \\
\hline 1989 & $\begin{array}{l}\text { Dwyer et } \\
\text { al. }^{7}\end{array}$ & 1 & 32/Female & Phalanx & $\begin{array}{l}\text { Swelling, } \\
\text { pain }\end{array}$ & $\begin{array}{l}\text { Curettage and } \\
\text { grafting }\end{array}$ & No & - & 17 \\
\hline \multirow[t]{5}{*}{1994} & $\begin{array}{l}\text { Panico et } \\
\text { al. }^{8}\end{array}$ & 5 & 31/Female & Metatarsal & NR & $\begin{array}{l}\text { Curettage and } \\
\text { grafting }\end{array}$ & No & - & 32 \\
\hline & & & 17/Male & Metatarsal & NR & $\begin{array}{l}\text { Curettage and } \\
\text { grafting }\end{array}$ & No & - & 33 \\
\hline & & & 16/Male & Phalanx & NR & $\begin{array}{l}\text { Curettage and } \\
\text { grafting }\end{array}$ & Yes & Curettage & 27 \\
\hline & & & 34/Female & Phalanx & NR & Resection & No & - & 30 \\
\hline & & & 41/Male & Metacarpal & NR & Resection & No & - & 65 \\
\hline 1997 & Giza et al. ${ }^{9}$ & 1 & 67/Female & Metacarpal & $\begin{array}{l}\text { Pain, } \\
\text { swelling }\end{array}$ & Amputation & No & - & 36 \\
\hline 1998 & $\begin{array}{l}\text { Bertoni et } \\
\text { al. }{ }^{10}\end{array}$ & 1 & 52/Male & Phalanx & Pain & $\begin{array}{l}\text { Curettage and } \\
\text { grafting }\end{array}$ & No & - & 24 \\
\hline 1998 & $\begin{array}{l}\text { Arenson et } \\
\text { al. }^{11}\end{array}$ & 1 & 19/Female & Metatarsal & $\begin{array}{l}\text { Pain, } \\
\text { swelling }\end{array}$ & $\begin{array}{l}\text { Resection and } \\
\text { reconstruction }\end{array}$ & No & - & 23 \\
\hline 1999 & $\begin{array}{l}\text { Ugwonali } \\
\text { et al. }^{12}\end{array}$ & 1 & 4.5/Female & Metacarpal & $\begin{array}{l}\text { Pathological } \\
\text { fracture }\end{array}$ & $\begin{array}{l}\text { Curettage and } \\
\text { grafting }\end{array}$ & Yes & $\begin{array}{l}\text { Resection and } \\
\text { reconstruction }\end{array}$ & 36 \\
\hline \multirow[t]{3}{*}{2000} & $\begin{array}{l}\text { Forouhar } \\
\text { et al. }^{13}\end{array}$ & 3 & 15/Female & Metatarsal & Pain & Amputation & No & - & 204 \\
\hline & & & 8/Female & Phalanx & Pain & $\begin{array}{l}\text { Curettage and } \\
\text { grafting }\end{array}$ & No & - & 24 \\
\hline & & & 12/Female & Phalanx & Pain & $\begin{array}{l}\text { Curettage and } \\
\text { grafting }\end{array}$ & Yes & $\begin{array}{l}\text { Resection and } \\
\text { reconstruction }\end{array}$ & 48 \\
\hline 2003 & $\begin{array}{l}\text { Gouin et } \\
\text { al. }^{14}\end{array}$ & 1 & 14/Female & Metatarsal & Pain & $\begin{array}{l}\text { Curettage and } \\
\text { grafting }\end{array}$ & No & - & 36 \\
\hline 2003 & $\begin{array}{l}\text { Macdonald } \\
\text { et al. }^{15}\end{array}$ & 1 & 25/Male & Metacarpal & $\begin{array}{l}\text { Pain, } \\
\text { swelling }\end{array}$ & $\begin{array}{l}\text { Resection and } \\
\text { reconstruction }\end{array}$ & No & - & 7 \\
\hline
\end{tabular}




\begin{tabular}{|c|c|c|c|c|c|c|c|c|c|}
\hline Year & Authors & $\begin{array}{l}\text { Number } \\
\text { of } \\
\text { patients }\end{array}$ & $\begin{array}{l}\text { Age } \\
\text { (years)/Gender }\end{array}$ & Site & Symptom & Treatment & Recurrence & $\begin{array}{l}\text { Treatment } \\
\text { after } \\
\text { recurrence }\end{array}$ & $\begin{array}{l}\text { Follow- } \\
\text { up } \\
\text { (months) }\end{array}$ \\
\hline \multirow[t]{2}{*}{2007} & $\begin{array}{l}\text { Yoshida et } \\
\text { al. }{ }^{16}\end{array}$ & 2 & 7/Female & Metacarpal & Pain & $\begin{array}{l}\text { Curettage and } \\
\text { grafting }\end{array}$ & Yes & $\begin{array}{l}\text { Curettage, } \\
\text { phenol and } \\
\text { ethanol } \\
\text { sterilizing, } \\
\text { and grafting }\end{array}$ & 84 \\
\hline & & & 23/Male & Metacarpal & Pain & $\begin{array}{l}\text { Curettage, } \\
\text { phenol and } \\
\text { ethanol } \\
\text { sterilizing, } \\
\text { and grafting }\end{array}$ & No & - & 36 \\
\hline 2008 & $\begin{array}{l}\text { Saghieh et } \\
\text { al. }{ }^{17}\end{array}$ & 1 & 13/Female & Metacarpal & $\begin{array}{l}\text { Pain, } \\
\text { swelling }\end{array}$ & $\begin{array}{l}\text { Resection and } \\
\text { reconstruction }\end{array}$ & No & - & 13 \\
\hline 2008 & $\begin{array}{l}\text { Cook et } \\
\text { al. }^{18}\end{array}$ & 1 & 26/Female & Phalanx & Pain & Resection & No & - & 24 \\
\hline 2011 & $\begin{array}{l}\text { Perkins et } \\
\text { al. }{ }^{19}\end{array}$ & 1 & 16/Male & Phalanx & Pain & $\begin{array}{l}\text { Curettage and } \\
\text { grafting }\end{array}$ & No & - & 8 \\
\hline 2012 & $\begin{array}{l}\text { Monacelli } \\
\text { et al. }^{20}\end{array}$ & 1 & 16/Male & Phalanges & NR & $\begin{array}{l}\text { Resection and } \\
\text { reconstruction }\end{array}$ & No & - & 6 \\
\hline 2016 & $\begin{array}{l}\text { Huan et } \\
\text { al. }^{21}\end{array}$ & 1 & 21/Female & Phalanx & $\begin{array}{l}\text { Pain, } \\
\text { swelling }\end{array}$ & $\begin{array}{l}\text { Resection and } \\
\text { reconstruction }\end{array}$ & No & - & 8 \\
\hline 2017 & $\begin{array}{l}\text { Telisselis } \\
\text { et al. }^{22}\end{array}$ & 1 & 16/Male & Metacarpal & NR & $\begin{array}{l}\text { Resection and } \\
\text { reconstruction }\end{array}$ & No & - & 24 \\
\hline 2020 & $\begin{array}{l}\text { Present } \\
\text { study }\end{array}$ & 1 & 16/Male & Phalanx & $\begin{array}{l}\text { Pain, } \\
\text { swelling }\end{array}$ & $\begin{array}{l}\text { Curettage and } \\
\text { grafting }\end{array}$ & Yes & $\begin{array}{l}\text { Resection and } \\
\text { reconstruction }\end{array}$ & 17 \\
\hline
\end{tabular}

Table 3

Collation and analysis of data in Table 2

\begin{tabular}{|llllll|}
\hline & Number of lesions & Recurrence number & Rate of recurrence & Treatment after recurrence & Final number of treatment \\
\hline Curettage & 25 & 9 & $36.0 \%$ & Curettage (3) & 19 \\
\hline Resection & 10 & 0 & & Resection (5) Amputation (1) & \\
\hline Amputation & 2 & 0 & 0 & 0 & 15 \\
\hline Total & 37 & 9 & 0 & 0 & 3 \\
& & & & Curettage (3) & $37.3 \%$ \\
\hline
\end{tabular}

\section{Discussion}

GCLSB is a very rare tumor-like lesion that occurs in hands and feet; it was newly defined in the WHO classification of tumors of soft tissue and bone in $2013^{1}$. Previously, it was known as giant cell reparative granuloma. In 1953, Jaffe first reported GCRG as a macrophage-rich bone lesion occurring in jaw bones; he emphasized that it was clinically and histologically different from giant cell tumors ${ }^{23}$. Later, it was found not only in the jaw bones, but also in bones throughout the body. In 1983, GCRG was reported in metacarpal, capitate, lunate bones for the first time ${ }^{2}$. It occurs particularly in the phalanx and metacarpal bones ${ }^{2}$. It tends to occur in adolescents in their second decades. Patients initially experience pain and swelling in the lesion site, and pathologic fractures may develop as the disease progresses ${ }^{1}$. Radiographically, there is an expanded osteolytic lesion in the metaphysis or diaphysis, with thinning of the cortical bone, but no destruction and no periosteal response. Histopathological examination shows spindle-shaped fibroblast hyperplasia with hemorrhage, hemosiderin deposits, irregularly distributed osteoclast-like giant cells and reactive bone formation. Osteoclast-like giant cells are smaller and have fewer nuclei than giant cell tumor of bone ${ }^{1}$. On genetic analysis, rearrangement of chromosomes 8 and 22 were found in a patient with GCRG of the jaw ${ }^{24}$. Nevertheless, it remains to be determined whether this rearrangement is prevalent in GCLSB. Because GCLSB is not rare, both radiologically and histologically, it is necessary to strictly follow the principle of clinical-image-pathology to make appropriate treatment decisions. 
To date, there have been no guidelines for treatment because of the low level of morbidity. According to our data in Table 2, surgeons tend to choose curettage and grafting. This results in minimal damage to function; however, it also carries the risk of recurrence. Phenol and ethanol were used by Yoshida et al. to reduce the recurrence rate ${ }^{16}$. In our case, ethanol did not prevent recurrence. The analysis shows that $36 \%$ of lesions recurred after curettage; however, none of resected lesions recurred. Only $51.3 \%$ of lesions were finally cured by curettage, while $43.2 \%$ of the lesions were cured by resection, and $5.4 \%$ of the lesions were cured by amputation (Table 3 ). Amputation is rarely chosen by surgeons. As it is an extreme form of surgery which lead to totally loss of function.

Resection and reconstruction is the treatment of choice. It not only cures the lesion without a second operation, but it also tends not to compromise function. Macdonald et al. reconstructed the lesion site with iliac crest bone grafting and fascial arthroplasty. His patient's grip strength and motion at metacarpophalangeal joint was preserved. ${ }^{15}$. For the young patient described in this report, the lesion occurred in the shaft of the proximal phalanx of the thumb. To prevent recurrence, we had to remove the proximal phalanx, interphalangeal joint, and metacarpophalangeal joint, and conduct joint fusion with bone grafting. Postoperative follow-up revealed slightly lower pinching power of the thumb. If we had tried to preserve the metaphysis and remove the diaphysis of phalanx with grafting during the first operation, the proximal phalanx, interphalangeal joint, and metacarpophalangeal joint could be retained, and the function of thumb might be better preserved.

\section{Conclusion}

In summary, we report a case of a 16-year-old man with recurrent GCLSB that was successfully resected with bone grafting. We conclude that resection and reconstruction with curettage is the treatment of choice.

\section{Abbreviations}

GCLSB, giant cell lesion of small bones; GCRG, giant cell reparative granuloma; MRI, magnetic resonance imaging

\section{Declarations}

\section{Ethics approval and consent to participate}

Not applicable.

\section{Consent for publication}

Informed consent was obtained from the patient.

\section{Availability of data and materials}

All data generated or analyzed during this study are included in this published article.

\section{Competing interests}

The authors have no potential conflicts of interest to disclose.

\section{Funding}

This work was supported by Industrial Independent Innovation Capability Project of Jilin Development and Reform Commission (Grant No. 2019C005, to ZZ); Jilin Scientific and Technological Development Program (Grant No. 20190905003SF, to ZZ). The funding sources had no role in study conception and design, data analysis or interpretation, paper writing or deciding to submit this paper for publication.

\section{Authors' contributions}

Jiannan Li wrote the initial draft. Zhan Zhang and Guangzhi Wu were the surgeon. Weizhong Zhang performed the pathological examination. All authors read and approved the final manuscript.

\section{Acknowledgements}

The authors thank Rhine Language Editing for assisting in the preparation of this paper.

\section{ORCID ID}

Jiannan Li https://orcid.org/ 0000-0001-9679-3823

\section{References}


1. Christopher DM, Fletcher; Julia ABridge;Pancras CW Hogendoorn; Fredrik Mertens. WHO Classification of Tumours of soft Tissue and Bone 4th edition. 2013:273.

2. Glass TA, Mills SE, Fechner RE, Dyer R, Martin W, Armstrong P. Giant-cell reparative granuloma of the hands and feet. Radiology. 1983;149(1):65-8. doi:10.1148/radiology.149.1.6611953.

3. Caskey PM, Wolf MD, Fechner RE. Multicentric giant cell reparative granuloma of the small bones of the hand. A case report and review of the literature. Clin Orthop Relat Res. 1985;NO:193:199-205. doi:10.1097/00003086-198503000-00029.

4. Merkow RL, Bansal M, Inglis AE. Giant cell reparative granuloma in the hand: Report of three cases and review of the literature. J Hand Surg Am. 1985;10(5):733-9. doi:10.1016/S0363-5023(85)80222-7.

5. Wenner SM, Johnson K. Giant cell reparative granuloma of the hand. J Hand Surg Am. 1987;12(6):1097-101. doi:10.1016/S03635023(87)80123-5.

6. Robinson D, Hendel D, Halperin N, Levin S. Multicentric giant-cell reparative granuloma: A case in the foot. Acta Orthop. 1989;60(2):232-4. doi:10.3109/17453678909149265.

7. Dwyer RT, Bilous AM, Nade S, Sullivan JA. Giant Cell Reaction in a Phalangeal Bone. Aust N Z J Surg. 1989;59(7):586-9. doi:10.1111/j.14452197.1989.tb01636.x.

8. Panico L, De Rosa N, D’Antonio A, De Rosa G, Passeretti U. Giant cell reparative granuloma of the distal skeletal bones - A report of five cases with immunohistochemical findings. Virchows Arch. 1994;425(3):315-20. doi:10.1007/BF00196155.

9. Giza E, Stern PJ, Cualing H. Aggressive giant cell reparative granuloma of the metacarpal: A case report. J Hand Surg Am. 1997;22(4):732-6. doi:10.1016/S0363-5023(97)80137-2.

10. Bertoni F, Biscaglia R, Bacchini P. Giant cell reparative granuloma of the phalanx of the hand with aggressive radiographic features. Skeletal Radiol. 1998;27(10):584-7. doi:10.1007/s002560050443.

11. Arenson DJ, Cohen MD. Structural and functional reconstruction after resection of aneurysmal bone cyst of the fifth metatarsal: A case study. Foot Ankle Int. 1998;19(6):405-10. doi:10.1177/107110079801900611.

12. Ugwonali O, Eisen RN, Wolfe SW. Repair of a multiply recurrent giant cell reparative granuloma of the hand with wide resection and fibular grafting. J Hand Surg Am. 1999;24(6):1331-6. doi:10.1053/jhsu.1999.1331.

13. Forouhar FA, Phelan NP, Benton DC. Giant cell reparative granuloma of the small bones of the hands and feet: A report of three cases. Ann Clin Lab Sci. 2000;30(3):272-7.

14. Gouin F, Grimaud E, Redini F, Moreau A, Passuti N, Heymann D. Metatarsal Giant Cell Tumors and Giant Cell Reparative Granuloma are Similar Entities. Clin Orthop Relat Res. 2003;(416):278-84. doi:10.1097/01.blo.0000093016.90435.f6.

15. Macdonald DF, Binhammer PA, Rubenstein JD, Fornasier VL. Giant cell reparative granuloma of the hand: Case report and review of giant cell lesions of hands and feet. Can J Surg. 2003;46(6):471-3.

16. Yoshida T, Sakamoto A, Tanaka K, Matsuda S, Oda Y, Iwamoto Y. Alternative Surgical Treatment for Giant-Cell Reparative Granuloma in the Metacarpal, Using Phenol and Ethanol Adjuvant Therapy. J Hand Surg Am. 2007;32(6):887-92. doi:10.1016/j.jhsa.2007.04.001.

17. Saghieh S, Sraj S, Lakkis S. Re. Is giant cell reparative granuloma of the hand undertreated? J Hand Surg Eur Vol. 2008;33(2):218-9. doi:10.1177/1753193408087096.

18. Cook DL, Rosenthal DC, Shikoff MD. Giant Cell Reparative Granuloma of the Middle Phalanx of the Foot: A Review and Case Report. J Foot Ankle Surg. 2008;47(6):589-93. doi:10.1053/j.jfas.2008.07.001.

19. Perkins A, Izadpanah A, Sinno H, Bernard C, Williams HB. Giant cell reparative granuloma of the proximal phalanx: A case report and literature review. Can J Plast Surg. 2011;19(2):e19-21. doi:10.1177/229255031101900205.

20. Monacelli G, Rizzo MI, Monarca C. Multicentric osteolytic lesion of the middle finger of the hand. Case report. G Chir. 2012;33(4):136-8.

21. Cm H, Norzila AB, Usm MMR. Bone Cyst in Proximal Phalanx of Toe. Malaysian Orthop J. 2016;10(1):55-6.

22. Telisselis P, Heers G, Obernhuber E. Das reparative Riesenzellgranulom des Os metacarpale: Differenzialdiagnostische Schwierigkeiten. Unfallchirurg. 2017;120(8):707-11. doi:10.1007/s00113-017-0336-z.

23. Jaffe HL. Giant-cell reparative granuloma, traumatic bone cyst, and fibrous (fibro-osseous) dysplasia of the jawbones. Oral Surgery Oral Med Oral Pathol. 1953;6(1):159-75. doi:10.1016/0030-4220(53)90151-0.

24. Johnsson A, Collin A, Rydholm A, Domanski HA, Mertens F, Mandahl N. Unstable translocation (8;22) in a case of giant cell reparative granuloma. Cancer Genet Cytogenet. 2007;177(1):59-63. doi:10.1016/j.cancergencyto.2007.04.017.

\section{Figures}



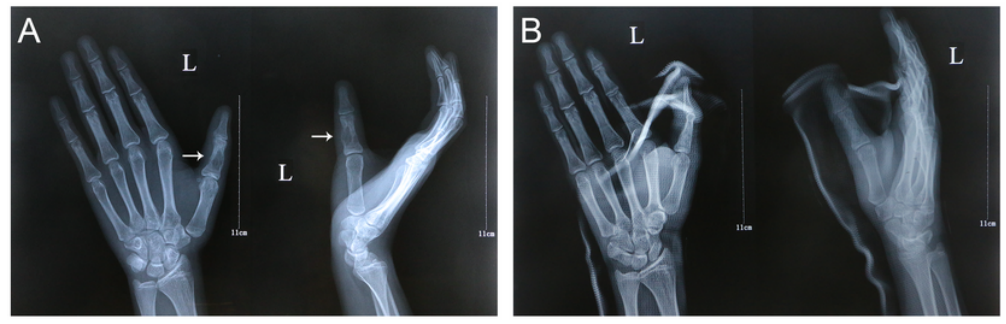

Figure 1

Pre- and postoperative images in 2017.07. (A) Lytic expansile lesion of the proximal phalanx of the left thumb on X-ray (white arrow). (B) The lesion was curetted. 

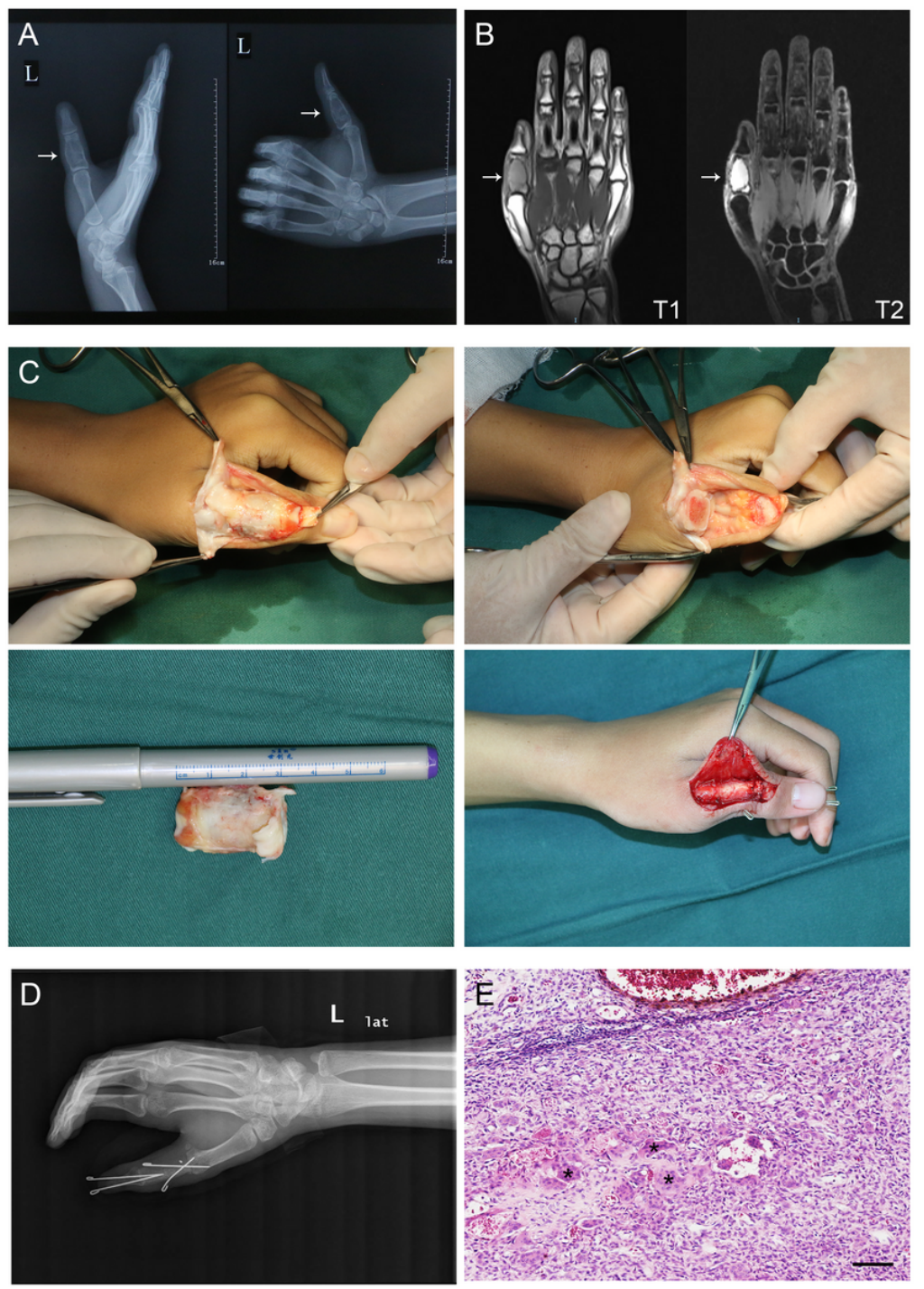

Figure 2

Preoperative, intraoperative and postoperative images in 2018.08 (A) Recurrent lesion of the proximal phalanx of left thumb on X-ray (white arrow). (B) MRI revealing the recurrent lesion (white arrow). (C) The lesion was resected with grafting, interphalangeal joint arthrodesis. The stop point of the adductor pollicis was reconstructed. (D) Postoperative images on X-ray. (E) Pathological examination revealing peculiar features of the giant cell lesion of small bones. Multinucleated giant cells (asterisks) are clustered in the lesion. Bar=100 $\mu \mathrm{m}$ 

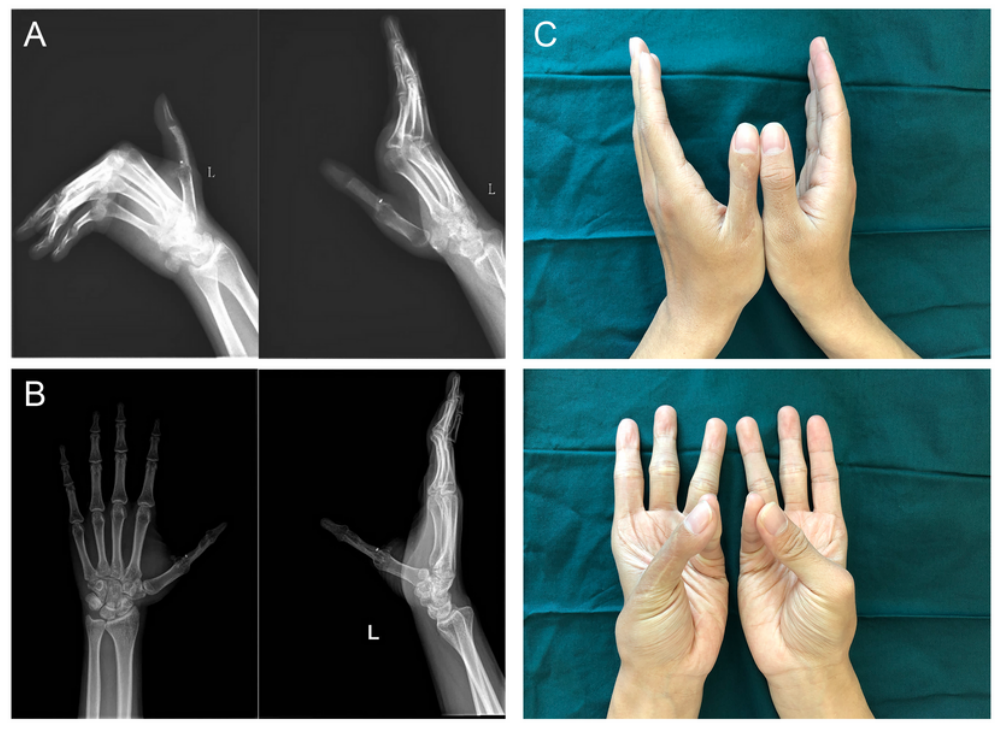

\section{Figure 3}

Post-surgical follow-up evaluation (A) X-ray revealing no local recurrence at 3-month follow-up. (B) X-ray revealing no local recurrence at 17-month follow-up. (C) The palm-to-palm test of the thumb was negative. 